Revista Brasileira de Farmacognosia Brazilian Journal of Pharmacognosy 21(4): 622-626, Jul./Aug. 2011

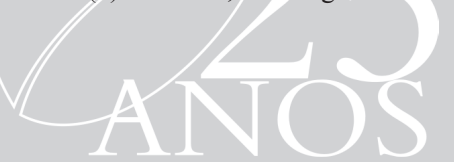

Article

Received 16 Jul 2010

Accepted 21 Feb 2011

Available online 24 Jun 2011

Keywords:

antiproliferative

Gaylussacia brasiliensis

medicinal plants

ISSN 0102-695X

doi: 10.1590/S0102-695X2011005000116

\section{Antiproliferative activity, isolation and identification of active compound from Gaylussacia brasiliensis}

\author{
Rodney Alexandre Ferreira Rodrigues, ${ }^{* 1}$ João Ernesto de \\ Carvalho, ${ }^{1}$ Ilza Maria de Oliveira Sousa, ${ }^{1}$ Marcia Aparecida \\ Antônio, ${ }^{2}$ Paulo Eduardo Pizão, ${ }^{2}$ Luciana Konecny Kohn, ${ }^{3}$ \\ Maria do Carmo Estanislau do Amaral, ${ }^{4}$ Volker Bittrich, ${ }^{4}$ Mary \\ Ann Foglio ${ }^{1}$
}

\author{
${ }^{I}$ Centro Pluridisciplinar de Pesquisas Químicas, Biológicas e Agrícolas, Universidade \\ de Campinas, Brazil, \\ ${ }^{2}$ Departamento de Clínica Médica, Faculdade de Ciências Médicas, Universidade de \\ Campinas, Brazil, \\ ${ }^{3}$ Departmento de Biologia Celular, Instituto de Biologia, Universidade de Campinas, \\ Brazil, \\ ${ }^{4}$ Departmento de Botânica, Instituto de Biologia, Universidade de Campinas, Brazil.
}

\begin{abstract}
Gaylussacia brasiliensis (Spreng.) Meissn., Ericaceae, is used in folk medicine for treatment of several inflammatory processes and as healing agent. The scope of this work was to evaluate the in vitro antiproliferative activity of crude dichloromethane extract (CHD) and to identify the compound(s) responsible for this activity. CHD was evaluated and showed a concentration dependent inhibition on all cells lines. Therefore CHD was submitted to several classical columns chromatography providing the most active fraction (FC), inhibiting all cells line at $25 \mu \mathrm{g} / \mathrm{mL}$. FC was further fractionated affording isolated compound $2 \beta, 3 \beta$-dihydroxy-urs-12-ene-28-oic acid, identified on basis of 2D-NMR experiments and showed concentration-dependent activity and selectivity for kidney and breast cell lines.
\end{abstract}

\section{Introduction}

Plants have been used as a source of medicine throughout history and continue to serve as the basis for many pharmaceuticals used today (Cragg et al., 2009). Natural products continue to play a major role for the discovery of chemotherapeutic agents or as leads for the development of modern medicines (Newman \& Cragg, 2007; Verpoort, 2000; Cragg et al., 1999; Cragg \& Newman, 1999; Verpoort, 1998). According to the world health organization (WHO), about three-quarters of the world population relies upon traditional remedies (mainly herbs) for health care of populations (Gilani \& Rahman, 2005). Over the last years, the interest in research on natural products has increased focusing on new chemotherapeutic substances and resulting in the discovery of more efficient drugs for many diseases and especially on cancer treatment, playing an important role in the development of chemotherapy (Newman, et al., 2003; Philipson, 2001; Calixto, 2000; Lee, 1999). The pharmaceutical industry widely implemented biochemical assays and high-throughput screening in the $1990 \mathrm{~s}$, and as a result, natural product screening programs have been de-emphasized (Rishton, 2008). During the past fifty years, plants have provided several more clinically used drugs. One of the most important examples is the Catharanthus alkaloids vinblastine and vincristine, currently used for treatment of leukemia, lymphomas and some solid tumors were introduced through the Eli Lilly Company in the 1960s. The NCI collaborative research programme into natural products with anticancer activity was initiated in 1957 , and between 1960 and 1986 more than 35000 species were screened against murine tumors and from eleven compounds approved for extensive tumor panel testing, two came into clinical use (Philipson, 2007). According to Walker \& Croteau (2001) and Schiff et al. (1979), other important example is the taxoids compounds (docetaxel and paclitaxel), obtained from Taxus genus species (Mattos et al., 2001; Pezzuto, 1997) and the camphtotecin derivates (irinotecan and topotecan), obtained from Camptotheca acuminata (Chang, 2000; Wall, 1998; Wall, et al. 1966).

Currently, over a hundred types of cancer are known, differentiated by etiology, natural history therapeutic and procedures. Notwithstanding the 
great evolution of basic knowledge concerning this pathology, it has not reflected in the development of efficient techniques of prevention and cure (Verdecchia et al., 2001; Verweij \& de Jonge, 2000).

In 1997; Chemical, Biological and Agricultural Research Center at State University of Campinas (Unicamp), with financial support from Fundação de Amparo à Pesquisa do Estado de São Paulo, established a research program in order to identify natural products with potential antineoplastic activity. Therefore, a survey of several plant species from the Brazilian cerrado was carried out (Denny et al., 2008). This region is a hotspot that harbors a great diversity of endemic species andovermore has been significantly impacted and altered by human activities (Myers et al., 2000). This biodiversity provides a great chemical variety encountered among the region, the relatively small amount of biologic knowledge and the fast cerrado extinction areas (Ferri, 1969). Gaylussacia brasiliensis (Spreng) Meissner, Ericaceae, was selected throughout the screening programm. This work evaluated the in vitro antiproliferative activity of extracts and isolated compound from G. brasiliensis, popularly known as "camarinha". This plant is an arbust, which could be found in the Atlantic Forest (Ilha do Mel, Paranaguá, Paraná State - Brazil) (Corrêa, 1984).

The genus Gaylussacia is known to present antifungal activity, probably due to the presence of phenolic compounds (Cipollini \& Stiles, 1992). Other known compounds in the genus include stilbene (Askari et al., 1972) and anthocyanin derivatives (Ballington et al., 1988). An update literature search has shown that the compounds present in this genus have not been evaluated for activity on the in vitro antiproliferative assay.

\section{Material and Methods}

\section{General experimental procedures}

The physical and spectral data $\left({ }^{1} \mathrm{H}-\mathrm{NMR},{ }^{13} \mathrm{C}\right.$ NMR) were recorded at 11.75 Tesla $(500 \mathrm{MHz}$ for $1 \mathrm{H}$ and $125 \mathrm{MHz}$ for ${ }^{13} \mathrm{C}$ ) using INOVA 500 spectrometer, tetramethylsylane was used as internal standard. Optical rotation on Polarimeter-Lep $\mathrm{A}_{2}$ with sodium lamp; IR spectra recorded on Bomen MB series Hartmann\& Braun-Michelson instrument TLC was performed on precoated aluminum sheets (Merck 5554). Compounds were visualized by spraying with $p$-anisaldehyde$\mathrm{H}_{2} \mathrm{SO}_{4}$-acetic acid $(0.5: 1: 50)$ followed by heating at $110-120{ }^{\circ} \mathrm{C}$ to yield blue, pink or purple spots. For column chromatography, Si 60 (70-230 mesh and 230400 mesh, Merck) All solvents were analytical grade and redistilled before use.

Gas chromatography/mass spectrometry analysis (GC/MS) were carried out using a HP$5890 / 5970$ system equipped with a J\&W Scientific CPSIL 24 CB fused capillary column $(30 \mathrm{~m} \mathrm{x} 0.25 \mathrm{~mm} \mathrm{x}$ $0.25 \mathrm{~m})$. Temperature program: $150{ }^{\circ} \mathrm{C}(2 \mathrm{~min}) ;\left(5^{\circ} \mathrm{C} /\right.$ $\min ) ; 240{ }^{\circ} \mathrm{C} ;\left(10{ }^{\circ} \mathrm{C} / \mathrm{min}\right) ; 300{ }^{\circ} \mathrm{C}(34 \mathrm{~min})$. Injector temperature: $280{ }^{\circ} \mathrm{C}$; detector temperature: $300{ }^{\circ} \mathrm{C}$. Helium was used as carrier gas (0.7 bar, $1 \mathrm{~mL} / \mathrm{min})$. The MS were taken at $70 \mathrm{eV}$. Scanning speed was 0.84 scans. $\mathrm{s}^{-1}$, from 40 to 550 atomic mass unit. Sample volume was $1 \mu \mathrm{L}$.

\section{Plant material}

The aerial parts of Gaylussacia brasiliensis (Spreng) Meissner, Ericaceae, were collected at "Reserva Biológica e Estação Experimental de Mogi Guaçu" in São Paulo State, Brazil (22¹5'07.18" S; 470'13.37' W) by botanists Maria do Carmo Estanislau do Amaral and Volker Bittrich. Voucher specimen is deposited at Instituto de Biologia, Unicamp, under registration number UEC-266.

\section{Crude extract and fractions preparation}

The material was grinded to a fine powder prior to use. The powder (500 g) was submitted to dynamic maceration with dichloromethane $(700 \mathrm{~mL})$ during $4 \mathrm{~h}$. This procedure was repeated three times with the same powder. After filtration, the solvent evaporated under vacuum at $40{ }^{\circ} \mathrm{C}$ resulted in the crude dichloromethane extract (CHD) with $9.6 \%$ yield.

The crude extract was pre-purified by dry column chromatography on silicagel 60 (Merck 7734) with chloroform/methanol $5 \%$ providing differents five fractions. The active Fraction $\mathrm{C}$ was further fractionated (10 g) on successive column chromatography using Silicagel (Merck 7734) $(5 \times 60 \mathrm{~cm})$ with hexane $/ \mathrm{CH}_{2} \mathrm{Cl}_{2}$ mixtures, affording compound $2 \beta, 3 \beta$-dihydroxy-urs12-ene-28-oic acid.

\section{Cell culture}

The experiments were performed using the following human cancer cell lines: MCF-7 (breast), NCI-ADR (ovarian expressing the multidrug resistance phenotype), NCI-460 (lung), UACC-62 (melanoma), 786-0 (renal), OVCAR-03 (ovarian), PC-03 (prostate) and HT-29 (colon). The National Cancer Institute, Frederick MA/USA, kindly donated these cell lines; and stock cultures were kept in liquid nitrogen.

Cells were cultured in $25 \mathrm{~cm}^{2}$ flasks (Nunc Brand Products) containing 5 mL of RPMI 1640 (Gibco BRL, Life Technologies.) with 5\% fetal bovine serum (Gibco BRL, Life Technologies). The cells are used up to twenty serial passages, afterwards they are discarded 
and new flasks are unfrozen for use.

\section{Biological assays}

All the adherent cell lines were detached from the culture flasks by addition of $0.5 \mathrm{~mL}$ of trypsin (Nutricell Nutrientes Celulares). Thereafter, trypsin was inactivated by addition of $5 \mathrm{~mL}$ of $5 \%$ serum in RPMI 1640 medium. Cells were separated into singlecell suspensions by a gentle pipetting action. After counting, the cells were diluted into appropriate seeding densities and inoculated onto 96-wells microtiter plates (Nunc Brand Products). Cells plating volume was 100 $\mu \mathrm{L}$ per well. Seeding densities varied among the cell lines as follows: $6.5 \times 10^{4}(\mathrm{MCF}-7) ; 5.0 \times 10^{4}(\mathrm{NCI}$ - ADR); $4.0 \times 10^{4}$ (NCI - 460); $3.0 \times 10^{4}$ (UACC62); $5.0 \times 10^{4}(786-0) ; 6.5 \times 10^{4}$ (OVCAR - 03); $4.5 \times$ $10^{4}(\mathrm{PC}-03)$ and $5.0 \times 10^{4}(\mathrm{HT}-29)$ cells per $\mathrm{mL}$. Microtiter plates containing cells were pre incubated for $24 \mathrm{~h}$ at $37^{\circ} \mathrm{C}$ in order to allow stabilization before the addition $(100 \mu \mathrm{L})$ of the test substance (crude extract, fractions and drugs). The plates were incubated with the test substance for $48 \mathrm{~h}$ at $37{ }^{\circ} \mathrm{C}$ and $5 \% \mathrm{CO}_{2}$. The positive controls of these experiments were DOX (doxorubicin) and TAM (tamoxifen) both from Sigma Chemical Company. These agents were tested at five 10 -fold concentrations, starting from with maximum concentration of $10^{-4} \mathrm{Mol}$ for DOX and $510^{-6} \mathrm{Mol}$ for TAM in RPMI/FBS/gentamicin (Chabner, 1993).

\section{Solubilization and dilution of test substance}

For initial screening, the crude extracts were tested at $250 \mu \mathrm{g} / \mathrm{mL}$. If antiproliferative activity was detected, the test substance was retested at four concentrations $(0.25 ; 2.5 ; 25 ; 250 \mu \mathrm{g} / \mathrm{mL})$, and each concentration was studied in triplicate wells. All samples were initially solubilized in dimethyl sulfoxide (Sigma Chemical Company) at 400 times the desired final maximum test concentration. Extracts stocks were stored frozen at minus $70{ }^{\circ} \mathrm{C}$. The concentrates were diluted with complete medium containing $50 \mu \mathrm{g} / \mathrm{mL}$ gentamicin (Schering - Plough).

\section{Assay antiproliferative - sulforhodamine B assay}

$(S R B)$

Sulforhodamine B (SRB) is an aminoxantine with a bright pink color that has two sulfonic groups. Since it is an anionic dye in weak acid solution it is capable of bonding to protein's aminoacids basic terminals cells fixed with trichloroacetic acid. Therefore this non-clonogenic methodology permits a high sensitive protein with a straight relationship to cell culture (Johnson, 1990; Skekan et al., 1990).
The SRB assay was performed according to the assay described by Skekan et al. (1990). Briefly, the cells were fixed by means of protein precipitation with 50\% trichloroacetic acid (TCA) (Sigma Chemical Company) at $4{ }^{\circ} \mathrm{C}(50 \mu \mathrm{L} /$ well, final concentration $10 \%$ ) for $1 \mathrm{~h}$. The supernatant was then discarded and the plates were washed five times with tap water. The cells were stained for 30 min with $0.4 \%$ the SRB (Sigma Chemical Company), dissolved in 1\% acetic acid (50 $\mu \mathrm{L} /$ well) (Sigma Chemical Company) and subsequently washed four times with $1 \%$ acetic acid to remove unbound stain. The plates were dried and bound protein stain was solubilized with $150 \mu \mathrm{L}$ of $10 \mathrm{mM}$ Trizma buffer (Sigma Chemical Company). The optical density was read on an automated spectrophotometer plate reader (Molecular Devices Versa Max Microplate Reader) at $540 \mathrm{~nm}$.

\section{Data calculations}

The optical density data were calculating according to Excel ${ }^{\circledR}$ program (Microsoft Office Package) and the values for mean \pm average standard error of data from replicated wells were calculated, from this the background optical measurements are subtracted from appropriated control well values and the appropriate drug-blank measurements. Cellular responses were calculated for growth stimulation, test substance effect, and growth inhibition. Three measurements were run at: a time zero (T0) value of SRB protein content at the beginning of test substance incubation, control value (C) at the end of the test substance incubation, and a set of test substance-treated test values (T) at the end of the test substance incubation period. If $\mathrm{T}$ was greater than or equal to T0 (cytostatic effect), the calculation was $100 \times[(\mathrm{T}-\mathrm{T} 0) /(\mathrm{C}-\mathrm{T} 0)]$. If $\mathrm{T}$ was less than $\mathrm{T} 0$, cell killing (cytocidal effect) occurred and was calculated from $100 \times$ [(T-T0)/T0]. The IC50 values (drugs concentration eliciting 50\% inhibition) were determinate by non linear regression analysis.

This results presented here refer to a representative experiment since all assays were run in triplicates the average standard error was always lower than $5 \%$.

\section{Results and Discussion}

Our phytochemistry studies were biomonitored throughout the cell growth percentages analysis on the antiproliferative assay. The criteria selection for those extract and/or fractions was growth percentage lower than $50 \%$ (negative values meaning cell death) and/or selective activity on a type of cell line, with a profile of concentration-dependent antiproliferative activity. The positive controls were the chemotherapeutic doxorubicin 
(DOX) and the antiestrogen agent tamoxifen (TAM).

In this study, aerial parts from Gaylussacia brasiliensis (Spreng) Meissner were initially extracted with dichloromethane and sequentially with $70 \%$ ethanol. The crude extracts were tested at concentrations from 0.25 to $250 \mu \mathrm{g} / \mathrm{mL}$ during for 48 h. The crude dichloromethane extract (CHD) presented the highest antiproliferative activity, inhibiting all cell lines with cellular death for OVCAR-03 (ovarian), PC03 (prostate) and 786-0 (renal) lines in a concentrationdependent relationship, whereas DOX showed no selectivity in its antiproliferative action (Table 1).

Subsequently, CHD was pre-purified by dry column chromatography over silica-gel affording five different fractions, from which fraction $\mathrm{C}$ (FC) was most active, inhibiting all cell lines at $25 \mu \mathrm{g} / \mathrm{mL}$. Fraction $\mathrm{C}$ obtained from CHD presented antiproliferative activity in all cell lines studied and was more potent than CHD. The IC50 values for all cell lines are listed in Table 1.

Table 1. Efficacies of CHD (dichloromethane extract), FC (fraction C), isolated compound from Gaylussacia brasiliensis (Spreng) Meissner and positive controls (DOX: doxorubicin and TAM: tamoxifen) against human tumoral cell lines, assessed by the Sulforhodamine B assay.

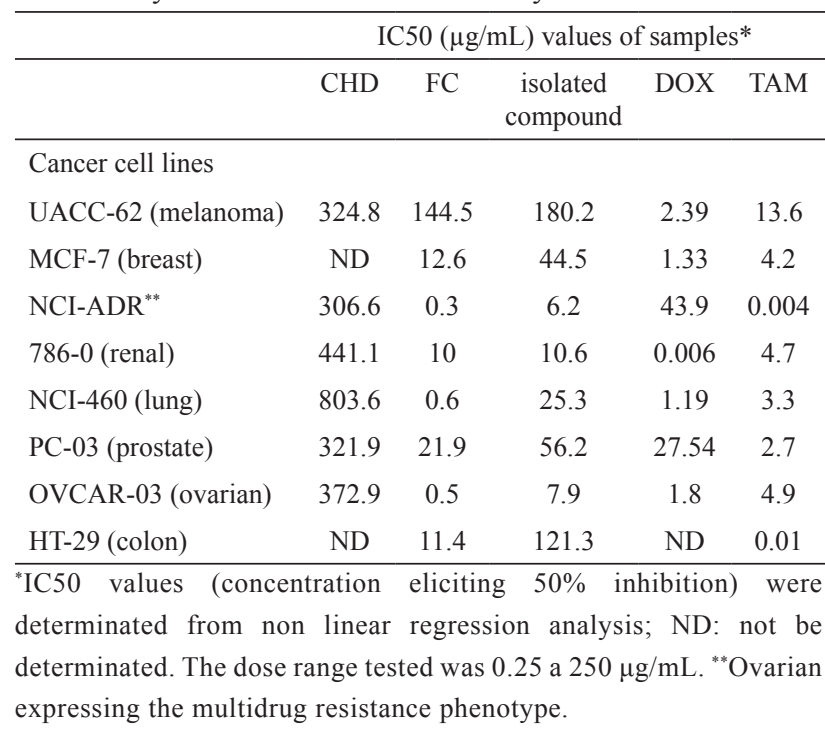

FC was further fractionated over silica-gel with hexane-ethyl acetate mixtures affording compound $2 \beta, 3 \beta$-dihydroxy-urs-12-ene-28-oic acid. The compound EIMS $(70 \mathrm{eV})$ mass spectrum showed $\left[\mathrm{M}^{+}\right]$at 470,683 corresponding to the formula $\mathrm{C}_{30} \mathrm{H}_{46} \mathrm{O}_{4}$.

Comparison of ${ }^{13} \mathrm{C}-\mathrm{NMR}$ shifts with those of the urs-12-en type described by Mahato \& Kundu (1994) suggested that isolated compound be $2 \beta, 3 \beta-$ dihydroxy-urs-12-ene-28-oic acid (1).

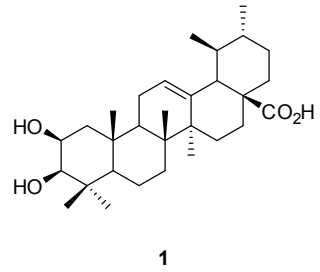

The isolated compound showed antitumoral activity with a concentration-dependent relationship, with cellular selectivity for 786-0 and MCF-7 cancer lines; the lowest IC50 was for NCI-ADR line with 6 $\mu \mathrm{g} / \mathrm{mL}$ (Table 1 ). The similarity of $2 \beta, 3 \beta$-dihydroxyurs-12-ene-28-oic acid to steroidal compound's activity was demonstrated by the inhibition of hormonedependent lines (ovarian, prostate and breast). This compound presented citotoxity for all cell lines from $70 \mu \mathrm{g} / \mathrm{mL}$ concentrations, in a straight concentrationdependent relationship, such as the positive control tamoxifen (Table 1). This result may suggest a possible connection of hormonal receptors and intracellular signalization with the pharmacological mechanism.

Some sterols such as the glucocorticoids are used in chemotherapy in order to prevent the proliferation of lymphocytes. Additional examples are estrogens (fosfestrol) prescribed for prostate cancer and progestogens (megestrol and medroxiprogesterone) for endometrium cancer (uterus). As hormonal antagonists used in chemotherapy there is the goserelin, which acts in inhibition of gonadotrofines' liberation in treatment of breast and prostate cancers, the tamoxifen (antiestrogen) for breast cancer and the flutamide used for prostate cancer (Calabresi \& Chabner, 2001).

Despite the high chemical purity of isolated compound, fraction $\mathrm{C}$ obtained from CHD presented was more potent, suggesting the presence of other compounds involved in the antiproliferative activity. Nowadays, studies on its mechanisms of action studies are being investigated and the bioassay guided isolation of other active components present in this fraction is also being carried out.

\section{Acknowledgements}

We would like to thank Sirlene Valério Tinti for competent and technical assistance. Fundação de Amparo a Pesquisa do Estado de São Paulo and Conselho Nacional de Pesquisas for financial support.

\section{References}

Askari A, Worthen LR, Shimizu Y 1972. Gaylussacin, a new stilbene derivative from a species of Gaylussacia. Lloyd 35: 49-54.

Ballington JR, Ballinger WE, Maness EP 1988. Anthocyanin, aglycone and aglycone-sugar content of fruits of 
temperate North American species of Gaylussacia (Eriaceae). Can J Plant Sci 68: 247-253.

Calabresi P, Chabner BA 2001. Chemotherapy of neoplastic diseases. In Hardmann JG, Limbird LE (eds.) Goodman and Gilman's, The Pharmacological Basis of Therapeutics. New York: McGraw Hill, p.1381.

Calixto JB 2000. Efficacy, safety, quality control, marketing and regulatory guidelines for herbal medicines (phytotherapeutic agents). Braz J Med Biol Res 33: 179-189.

Chabner BA 1993. Anticancer drugs. In De Vita, VT, Hellman S, Rosenberg SA (eds.) Cancer: Principles and practice of oncology. 4 ed. Philadelphia: J. B. Lippincott Company.

Chang J 2000. Medicinal herbs: drugs or dietary supplements? Biochem Pharmacol 59: 211-219.

Cipollini ML, Stiles EW 1992. Antifungal activity of ripe ericaceous fruits: phenolic-acid interactions and palatability for dispersers. Biochem Syst Ecol 20: 501-514.

Corrêa MP 1984. Dicionário de plantas úteis do Brasil e das exóticas cultivadas. vol. 4. Rio de Janeiro: Ministério da Agricultura, p. 689.

Cragg GM, Boyd MR, Khanna R, Kneller R, Mays TD, Mazan KD, Newman DJ, Sausville EA 1999. International collaboration in drug discovery and development: the NCI experience. Pure Appl Chem 71: 1619-1633.

Cragg GM, Newman DJ 1999. Discovery and development of antineoplasic agents from natural sources. Cancer Invest 17: 153-163.

Cragg GM, Grothaus PG, Newman DJ 2009. Impact of natural products on developing new anti-cancer agents. Chem Rev 109: 3012-3043.

Denny C, Zacharias M, Ruiz ALTG, Kohn LK, Amaral MCE, Bittrich V, Sousa IMO, Rodrigues RAF, Carvalho JE, Foglio MA 2008. Antiproliferative properties of polyketides isolated from Virola sebifera leaves. Phytotherapy Res 22: 127-130.

Ferri MG 1969. Plantas do Brasil. Espécies do cerrado. São Paulo: Edgard Blücher, p. 239.

Gilani AH, Rahman AU 2005. Trends in ethnopharmacology. J Ethnopharmacol 100: 43-49.

Johnson RK 1990. Screening methods in antineoplastic drug discovery. J Natl Cancer Inst 82: 1082-1083.

Lee KH 1999. Novel antitumoral agents from higher plants. Medical Res Rev 19: 569-596.

Mahato SB, Kundu AP 1994. ${ }^{13} \mathrm{C}$ NMR spectra of pentacyclic triterpenoids-a compilation and some salient features. Phytochemistry 37: 1517-1575.

Mattos DMM, Gomes ML, Freitas RS, Bernardo-Filho M 2001. Model to evaluate the toxic effect of drugs: vincritine effect in the mass of organs and in the distribution of radiopharmaceuticals in mice. Mutat Res 496: 137-143.

Myers N, Mittermeier RA, Mittermeier CG, da Fonseca GAB, Kents J 2000. Biodiversity hotspots for conservation priorities. Nature 403: 853-858.
Newman DJ, Cragg GM, Snader KM 2003. Natural products as sources of new drugs over the period 1981-2002. $J$ Nat Prod 66: 1022-1037.

Newman DJ, Cragg GM 2007. Natural products as sources of new drugs over the last 25 years. $J$ Nat Prod 70: 461477.

Pezzuto JM 1997. Plant derived anticancer agents. Biochem Pharmacol 53: 121-133.

Phillipson JD 2001. Phytochemistry and medicinal plants. Phytochemistry 56: 237-243.

Phillipson JD 2007. Phytochemistry and pharmacognosyreview. Phytochemistry 68: 2960-2972.

Rishton GM 2008. Natural products as a robust source of new drugs and drug leads: past successes and present day issues. Am J Cardiol 101: 43D-49D.

Schiff PB, Fant J, Horwitz SB 1979. Promotion of microtubule assembly in vitro by taxol. Nature 277: 665-667.

Skehan P, Storeng R, Scudiero D, Monks A, McMahon J, Vistica D, Warren JT, Bokesch H, Kenney S, Boyd MR 1990. New colorimetric cytotoxicity assay for anticancer-drug screening. J Natl Cancer Inst 82: 1107-1112.

Verdecchia A, Mariotto A, Capocaccia R, Gatta G, Micheli A, Sant M, Berrino F 2001. Incidence and prevalence of all cancerous disease in Italy: trends and implication. Eur J Cancer 37: 1149-1157.

Verpoorte R 1998. Exploration of nature's chemodiversity: the role of secondary metabolites as leads in drug development. Drug Develop Trends 3: 232-238.

Verpoorte R 2000. Pharmacognosy in the new millennium: leadfinding and biotechnology. J Pharm Pharmacol 52: 253-262.

Verweij J, De Jonge MJ 2000. Achievements and future of Chemotherapy. Eur J Cancer 36: 1479-1487.

Walker K, Croteau R 2001. Taxol biosynthesis: molecular cloning of a benzoyl-CoA: taxane2O-benzoyltransferase cDNA from Taxus and functional expression in Escherichia coli. Proc Natl Acad Sci 97: 13591-13596.

Wall ME, Wani MC, Cook CE, Palmer KH, McPhail AT, Sim GA 1966. Plant antitumor agents I. The isolation and structure of camptothecin, a novel alkaloidal leukemia and tumor inhibitor from Camptotheca acuminata. $J \mathrm{Am}$ Chem Soc 88: 3888-3890.

Wall ME 1998. Camptothecin and taxol: discovery to clinic. Med Res Rev 18: 299-314.

\section{*Correspondence}

Rodney Alexandre Ferreira Rodrigues

Centro Pluridisciplinar de Pesquisas Químicas, Biológicas e Agrícolas, Universidade de Campinas

Caixa Postal 6171, 13081-970, Campinas, São Paulo, Brazil rodney@cpqba.unicamp.br

Tel.: ++ 551921392862

Fax: ++ 551921392850 